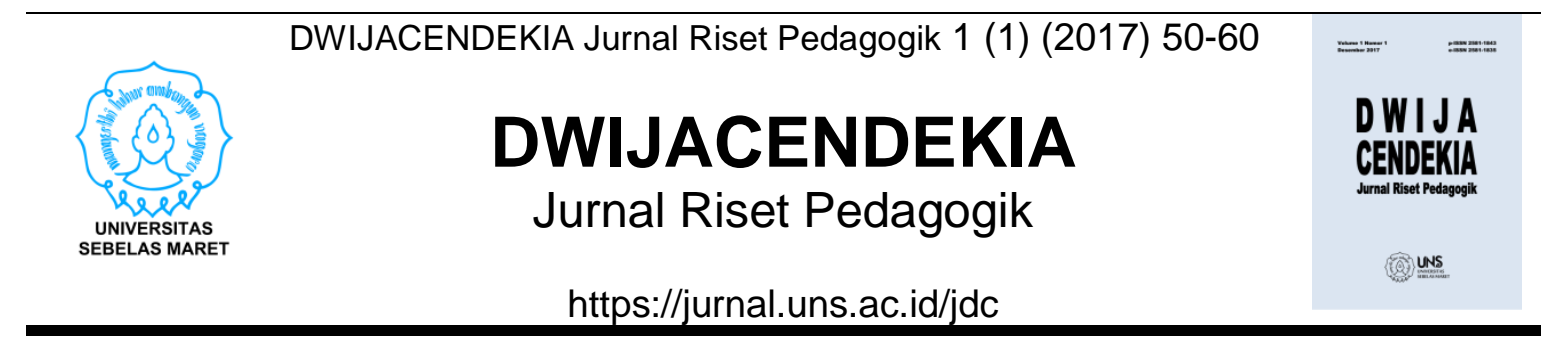

\title{
PENERAPAN MODEL PENEMUAN TERBIMBING UNTUK MENINGKATKAN HASIL BELAJAR IPA SISWA SEKOLAH DASAR
}

\section{Ika W. Utamining Tias}

STKIP PGRI Metro

\section{Sejarah Artikel \\ Diterima 3 Juli 2017 \\ Disetujui 10 Juli 2017 \\ Diterbitkan 1 Agustus 2017}

\section{Kata Kunci}

hasil belajar, IPA, model penemuan terbimbing

\begin{abstract}
Abstrak
Masalah dalam penelitian ini adalah rendahnya hasil belajar siswa IPA karena lebih dominan berorientasi pada produk dan bukan pada proses. Penelitian ini dilakukan untuk meningkatkan hasil belajar IPA siswa kelas $\mathrm{V}$ dengan menerapkan model penemuan terbimbing. Jenis penelitian yang digunakan adalah Penelitian Tindakan Kelas (PTK). Prosedur penelitian berbentuk siklus yang terdiri dari empat tahap meliputi perencanaan, pelaksanaan, observasi, dan refleksi. Penelitian ini dilaksanakan dalam 2 siklus. Teknik pengumpulan data dilakukan secara observasi dan tes. Teknik analisis yang digunakan adalah analisis kualitatif dan kuantitatif. Hasil penelitian menunjukkan hasil belajar IPA kelas V SD Negeri 10 Metro Timur meningkat pada persentase ketuntasan hasil belajar dari siklus I sebesar $63,33 \%$ menjadi $86,67 \%$ pada siklus II
\end{abstract}

\section{Cara Mengutip}

Tias, I.W.U. (2017). Peningkatan Keterampilan Menulis Deskripsi Melalui Penggunaan Media Gambar Berseri di Kelas IV SD Negeri 01 Daya Asri Kabupaten Tulang Bawang Barat. Dwija Cendekia Jurnal Riset Pedagogik, 1(1), 50-60.

Korespondensi Penulis: 


\section{PENDAHULUAN}

Ilmu Pengetahuan Alam (sains) sebagai bagian dari pendidikan di sekolah dasar dapat dipandang sebagai tahap awal dalam upaya formal untuk memberikan bekal kepada murid. Lebih lanjut, disebutkan bahwa betapa pentingnya pendidikan IPA di sekolah dasar yang akan menjadi dasar bagi perkembangan anak-anak selanjutnya, dan sebagain dari mereka merupakan satu-satunya pendidikan formal yang akan mereka peroleh selama hidupnya (Dahar, 1990). Menurut Khairudin dan Soedjono, (2005: 15), menyatakan bahwa IPA bukan hanya sekedar menghafalkan konsep dan prinsip IPA melainkan, dengan pembelajaran IPA diharapkan siswa dapat memiliki sikap dan kemampuan yang berguna bagi dirinya dalam memahami perubahan yang terjadi dilingkungannya dan berprestasi dalam pelajaran IPA.IImu Pengetahuan Alam (IPA) berhubungan dengan cara mencari tahu tentang alam secara sistematis, sehingga IPA bukan hanya penguasaan kumpulan pengrtahuan yang berupa fakta-fakta, konsepkonsep, atau prinsip-prinsip saja tetapi juga merupakan suatu proses penemuan. Pendidikan IPA diharapkan dapat menjadi wahana bagi peserta didik untuk mempelajari diri sendiri dan alam sekitar, serta prospek pengembangan lebih lanjut dalam menerapkan di dalam kehidupan sehari-hari. Proses pembelajaran menekankan pada pemberian pengalaman langsung untuk mengembangkan kompetensi agar menjelajahi dan memahami alam sekitar secara alamiah.
Pada dasarnya pembelajaran IPA bertujuan untuk menyiapkan peserta didik agar tanggap menghadapi lingkungannya, karena dengan belajar IPA siswa dapat belajar memahami fenomena-fenomena alam yang terjadi dilingkungannya. Menurut Badan Standar Nasional Pendidikan (BNSP) menjelaskan, mata pelajaran IPA di SD bertujuan agar peserta didik memiliki kemampuan sebagai berikut: (1) Memperoleh keyakinan terhadap kebesaran Tuhan Yang Maha Esa berdasarkan keberadaan, keindahan dan keteraturan alam ciptaan-Nya, (2) Mengembangkan pengetahuan dan pemahaman konsep-konsep IPA yang bermanfaat dan dapat diterapkan dalam kehidupan sehari-hari, Mengembangkan rasa ingin tahu, sikap positif dan kesadaran tentang adanya hubungan yang saling mempengaruhi antara IPA, lingkungan, tekhnologi dan masyarakat, (4) Mengembangkan keterampilan proses untuk menyelidiki alam sekitar, memecahkan masalah dan membuat keputusan, (5) Meningkatkan kesadaran untuk berparan serta dalam memelihara, menjaga dan melestarikan lingkungan alam, (6) Meningkatkan kesadaran untuk menghargai alam dan segala keteraturannya sebagai salah satu ciptaan Tuhan, (7) Memperoleh bekal pengetahuan, konsep dan keterampilan IPA sebagai dasar untuk melanjutkan pendidikan ke SMP/MTs.

Masalah yang dihadapi dunia pendidikan kita adalah masalah lemahnya proses pembelajaran. Dalam proses pembelajaran siswa kurang didorong untuk mengembangkan kemampuan berpikir kritis dan sistematis. Proses 
pembelajaran lebih diarahkan kepada kemampuan siswa untuk menghafal informasi. Otak siswa dipaksa untuk mengingat dan menimbun berbagai informasi tanpa dituntut untuk memahami informasi tersebut dan tidak berupaya untuk menghubungkannya dengan kehidupan sehari-hari. Akibatnya ketika peserta didik kita lulus dari sekolah, mereka pintar secara teoritis, tetapi kurang dalam tataran aplikatif. Pembelajaran IPA yang mendorong untuk menekankan pada pemberian pengalaman belajar secara langsung melalui penggunaan dan pengembangan keterampilan proses dan sikap ilmiah ketika mereka difasilitasi untuk mengkonstruksi sendiri pengetahuannya, dikenal sebagai pembelajaran IPA yang menggunakan pendekatan inkuiri ilmiah (scientific inquiry). Pembelajaran IPA sebagai mata pelajaran di SD lebih bersifat memberi pengetahuan, melalui pengamatanpengamatan, mengenai pelbagai jenis dan perangai lingkungan alam serta lingkungan buatan; mendorong siswa agar dapat menerapkan pengetahuannya untuk membantu proses berpikir atau mengembangkan pola pikirnya dalam memecahkan masalah-masalah IPA yang berhubungan dengan kehidupan sehari-hari. Namun pada kenyataannya banyak para pengajar masih memberikan cara mengajar yang berpatokan pada sistem lama, yaitu memberikan siswa materi tanpa mendorong siswa untuk menemukan atau menyelesaikan masalahnya sendiri. Guru sebagai ujung tombak yang menentukan keberhasilan pendidikan dan pengajaran disekolah, sepertinya belum mengantisipasi keadaan dan keperluan siswa. Sebagian guru sekolah dasar masih menggunakan pola lama, yaitu proses pembelajaran satu arah yang didominasi oleh guru melalui metode ceramah dan masih kurang melibatkan siswa untuk aktif dalam proses belajar mengajar. Dalam pembelajaran, guru hanya bersikap sebagai pelaksana tugas dalam pembelajaran, bukan memberikan pengalaman belajar yang bermakna kepada siswanya. Akibatnya, sains dianggap pelajaran hafalan. Cara mengajar yang kurang baik disebabkan para pengajar tidak mempunyai motivasi untuk mengajar, bahkan mereka tidak mengetahui bagaimana cara mengajar IPA dan mereka hanya memiliki sedikit pengetahuan tentang IPA.

Keadaan ini setidaknya teramati dari hasil observasi pelaksanaan pembelajaran IPA di salah satu SD Negeri di kota Metro, yang menunjukkan bahwa 1) Proses pembelajaran yang dilakukan oleh guru lebih dominan adalah metode ceramah, dimana guru berperan sebagai pusat pembelajaran; 2) Jarang sekali siswa terlibat aktif selama proses pembelajaran, terutama untuk aktivitas penyelidikan ilmiah 3) Pembelajaran IPA lebih dominan berorientasi pada produk dan bukan pada proses. Dengan pembelajaran seperti itu sudah dapat ditebak hasilnya, jangankan dalam tataran aplikasi dan keterampilan proses dalam hal pengetahuan saja hasil belajar IPA mereka masih tergolong rendah.Salah satu model pembelajaran yang memungkinkan membantu guru berperan sebagai pembimbing dan fasilitator utuh serta membuat siswa akan belajar menjadi lebih terarah dalam mencapai tujuan yang telah ditetapkan adalah model penemuan terbimbing. Siswa tidak 
dengan sendirinya menemukan sendiri konsep-konsep tanpa arahan dan bimbingan dari guru. Dalam proses pembelajaran yang menggunakan model penemuan terbimbing dapat terlihat besarnya motivasi dan tingkat berpikir mahasiswa terhadap masalah yang diajukan.

Menurut Davis dalam Markaban (2006) penemuan adalah suatu proses. Proses penemuan dapat menjadi kemampuan umum melalui latihan pemecahan masalah, praktek membentuk dan menguji hipotesis. Di dalam pandangan Bruner, belajar dengan penemuan adalah belajar untuk menemukan, di mana seorang siswa diarahkan untuk mendapatkan suatu kesimpulan dari serangkaian aktivitas yang dilakukan sehingga siswa seolah-olah menemukan sendiri pengetahuan tersebut. Model penemuan terbimbing yang dipandu oleh guru dikembangkan dalam suatu model pembelajaran yang dapat diselenggarakan secara individu atau kelompok. Model ini sangat bermanfaat dan sesuai dengan karakteristik mata pelajaran IPA. Guru membimbing siswa jika di perlukan dan siswa didorong untuk berpikir sendiri sehingga dapat menemukan prinsip umum berdasarkan bahan yang disediakan oleh guru dan sampai seberapa jauh siswa dibimbing tergantung pada kemampuannya dan materi yang sedang dipelajari.Dengan model pembelajaran penemuan terbimbing ini siswa dihadapkan kepada situasi dimana siswa bebas menyelidiki dan menarik kesimpulan. Terkaan, intuisi dan mencoba-coba (trial and error), hendaknya dianjurkan. Guru sebagai penunjuk jalan dalam membantu siswa agar mempergunakan ide, konsep dan keterampilan yang sudah mereka pelajari untuk menemukan pengetahuan yang baru.

Model pembelajaran penemuan terbimbing lebih banyak diterapkan, karena dengan petunjuk guru siswa akan bekerja lebih terarah dalam rangka mencapai tujuan yang telah ditetapkan. Namun, bimbingan guru bukanlah semacam resep yang harus diikuti tetapi hanya merupakan arahan tentang prosedur kerja yang diperlukan. Dalam belajar penemuan, peranan guru dapat dirangkum sebagai berikut: 1). Guru merencanakan pembelajaran sedemikian rupa sehingga pelajaran itu terpusat pada masalah-masalah yang tepat untuk diselidiki oleh para siswa 2). Guru hendaknya mulai dengan sesuatu yang sudah dikenal oleh siswa, kemudian guru mengemukakan sesuatu yang berlawanan. Dengan demikian, terjadilah konflik dengan pengalaman siswa 3). Guru hendaknya menggunakan cara penyajian yang sesuai dengan tingkat kognitif siswa 4). Guru sebagai fasilitator yang sebaiknya memberikan umpan balik pada waktu yang tepat (Dahar, 1996:107).

Setiap model pembelajaran memiliki kelebihan dan kelemahan masingmasing, Mulyani Sumantri dan Johar dalam Hadiningsih (2009:33) mengemukakan kelebihan dan kelemahan dari model penemuan terbimbing. Kelebihan model penemuan terbimbing (1) Dianggap membantu siswa mengembangkan atau memperbanyak persediaan dan penguasaan keterampilan dari proses kognitif siswa, andai kata siswa itu dilibatkan terus dalam penemuan terbimbing; (2) Pengetahuan diperoleh 
dari strategi ini sangat pribadi sifatnya dan mungkin merupakan suatu pengetahuan yang sangat kukuh, dalam arti pendalaman dari pengertian, retensi dan transfer; (3) Model pembelajaran penemuan terbimbingmembangkitkan gairah pada siswa, misalnya siswa merasakan jerih payah penyelidikan, menemukan keberhasilan dan kadang-kadang kegagalan; (4) Model pembelajaran penemuan terbimbingmemberikan kesempatan pada siswa untuk bergerak maju sesuai dengan kemampuannya sendiri; (5) Model pembelajaran penemuan terbimbingmenyebabkan siswa mengarahkan sendiri cara belajarnya, sehingga siswa lebih merasa terlibat dan termotivasi sendiri untuk belajar; (6) Model pembelajaran penemuan terbimbingdapat membantu dan memperkuat pribadi siswa dengan bertambahnya kepercayaan pada diri sendiri melalui proses-proses penemuan terbimbing. Dapat memungkinkan siswa sanggup mengatasi kondisi yang mengecewakan; (7) Model pembelajaran penemuan terbimbingberpusat pada siswa, misalnya memberi kesempatan pada siswa, dan guru berpartisipasi untuk mengecek ide. Guru menjadi pembimbing belajar, terutama dalam situasi guided discovery yang jawabannya belum diketahui siswa sebelumnya (8) Membantu perkembangan siswa dalam menemukan kebenaran akhir yang mutlak. Sedangkan, kekurangan model penemuan terbimbing adalah (1) Dipersyaratkan keharusan adanya persiapan mental untuk cara belajar ini; (2) Pendekatan pembelajaran guided discovery kurang baik untuk mengajar kelas besar; (3) Harapan yang ditumpahkan pada model ini mungkin mengecewakan guru dan siswa yang sudah biasa dengan perencanaan dan pengajaran secara tradisional; (4) Mengajar dengan guided discovery mungkin akan dipandang sebagai terlalu mementingkan perolehan pengertian dan kurang memperhatikan diperolehnya sikap dan keterampilan. Sedangkan sikap dan keterampilan diperlukan untuk memperoleh pengertian atau sebagai perkembangan emosional sosial secara keseluruhan.

Menurut Sudjana (2005) langkahlangkah yang sesuai dengan karakteristik model penemuan terbimbing/guided discovery, adalah sebagai berikut:

a. merumuskan masalah untuk dipecahkan siswa

b. menetapkan jawaban sementara/hipotesis,

c. siswa mencari informasi, data, fakta yang diperlukan untuk menjawab permasalahan atau hipotesis,

d. menarik kesimpulan jawaban atau generalisasi,

e. mengaplikasikan kesimpulan atau generalisasi dalam situasi baru.

Dari pendapat tersebut dapat disimpulkan bahwa model pembelajaran penemuan terbimbing adalah pembelajaran dimana peserta didik berpikir sendiri sehingga dapat "menemukan". Prinsip umum yang diinginkan dengan bimbingan dan petunjuk dari guru berupa pertanyaanpertanyaan yang mengarah. Pembelajaran penemuan terbimbing merupakan salah satu bagian dari pembelajaran penemuan yang melibatkan siswa dalam kegiatan belajar mengajar. Pembelajaran 
dengan penemuan, siswa didorong untuk belajar sebagian besar melalui keterlibatan aktif siswa sendiri dengan konsep-konsep dan prinsip-prinsip.
Selain itu, dalam pembelajaran penemuan siswa belajar pemecahan masalah secara mandiri dengan keterampilan-keterampilan berpikir.

\section{METODE PENELITIAN}

Metode penelitian menggunakan metode Penelitian Tindakan Kelas. Prosedur penelitian yang digunakan berbentuk siklus yang mengacu pada model Elliot's (Hopkins, 1993). Siklus ini tidak hanya berlangsung satu kali, tetapi beberapa kali hingga tercapai tujuan yang diharapkan dalam perbaikan pembelajaran. Dalam setiap siklus terdiri atas empat kegiatan pokok, yaitu :

a. Perencanaan (plan)

b. Pelaksanaan (act)

c. Pengamatan (observe), dan

d. Refleksi (reflect) (Hopkins, 1993)

Penelitian ini akan dilakukan secara kolaboratif partisipatif antara dosen PGSD STKIP PGRI Metro dengan guru-guru SD Negeri 10 Metro Timur. Subjek dalam penelitian ini adalah siswa dan guru kelas V SD Negeri 10 Metro Timur, Kota Metro. Teknik penguimpulan data dilakukan berdasarkan macam data yang diperlukan. Peneliti mengumpulkan data yang telah diperoleh berdasarkan instrumen penelitian, kemudian data diberi kode tertentu berdasarkan jenis dan sumbernya. Selanjutnya seluruh data diinterpretasi sesuai dengan tujuan penelitian. Alat pengumpul data berupa (a) Lembar panduan observasi, instrumen ini dirancang peneliti berkolaborasi dengan guru kelas. Lembar observasi ini digunakan untuk mengumpulkan data mengenai kinerja guru dan aktivitas belajar siswa selama penelitian tindakan kelas; (b) Pedoman wawancara, instrumen ini juga dirancang oleh peneliti berkolaborasi dengan tim peneliti. Pedoman ini digunakan untuk menjaring data berkaitan dengan rencana pelaksanaan tindakan, pandangan dan pendapat tim serta siswa terhadap penerapan media audio visual dalam pembelajaran IPA; (c) Tes hasil belajar, instrumen ini digunakan untuk menjaring data mengenai kemajuan hasil belajar sehubungan dengan topik bahasan yang menerapkan model pembelajaran penemuan terbimbing

\section{PEMBAHASAN}

Siklus I dilaksanakan sebanyak 2 kali pertemuan. Tahap perencanaan, sebelum dilaksanakan proses pembelajaran, peneliti melakukan persiapan sebagai berikut: menyiapkan silabus untuk menyusun rencana perbaikan pembelajaran dengan menggunakan model penemuan terbimbing untuk tindakan siklus I, menyiapkan alat peraga dan media pembelajara, menyiapkan lembar observasi untuk melihat kinerja guru selama pembelajaran, menyiapkan LKS yang diberikan pada siswa untuk lebih mudah memahami materi. Tahap pelaksanaanpertemuan 1, kegiatan pembelajaran berlangsung selama 2 
jam pelajaran (2x35 menit), dengan tema gaya magnt. Pada siklus I pertemuan 2, kegiatan pembelajaran berlangsung selama 2 jam pelajaran (2×35 menit), dengan tema gaya gesek. Pada tahap pengaman, dilakukan guru sebagai pengajar, dan dosen sebagai peneliti dan observer. Observasi dilaksanakan secara langsung bersamaan dengan kegiatan pembelajaran berdasarkan lembar observasi yang telah dibuat dan disusun indikatornya. Dari pengamatan pada siklus I, masih terdapat siswa yang kurang aktif. Hal ini dikaranakan siswa masih belum terbiasa kerja kelompok. Terdapat siswa yang bermain-main dengan temannya, ada yang terlihat sibuk sendiri, kurang adanya interaksi siswa dengan guru. Hasil observasi meliputi hasil kinerja guru dan hasil belajar siswa diuraikan sebagai berikut Analisis data hasil observasi menggunakan analisis persentase. Berdasarkan hasil penelitian kinerja guru selama proses pembelajaran pada siklus I pertemuan 1 dan 2 diperoleh hasil pada tabel 1 .

Tabel 1. Rekapitulasi Instrumen Penilaian Kinerja Guru Siklus I

\begin{tabular}{|c|c|c|c|c|c|}
\hline No & Siklus I & Skor & \multicolumn{3}{|c|}{ Kategori } \\
\cline { 4 - 6 } & & & A & CA & KA \\
\hline 1 & Pert 1 & $\begin{array}{c}84 \\
(72,41 \%)\end{array}$ & $\sqrt{ }$ & - & - \\
\hline 2 & Pert 2 & $\begin{array}{c}86 \\
(74,14 \%)\end{array}$ & $\sqrt{ }$ & - & - \\
\hline \multicolumn{2}{|c|}{$\begin{array}{c}\text { Rata-rata } \\
\text { siklus 1 }\end{array}$} & $73,27 \%$ & - & - & - \\
\hline
\end{tabular}

Berdasarkan hasil dari tabel instrumen penilaian kinerja guru pada pertemuan 1 jumlah skor yang diperoleh84 dengan $72,41 \%$ dengan kategori aktif, sedangkan pada pertemuan 2 aktivitas persentase guru meningkat menjadi $74,14 \%$ dengan jumlah skor 86, diperoleh rata-rata aktivitas guru pada siklus I $73,27 \%$ dengan kategori aktif, dan terlihat peningkatan sebesar $1.73 \%$.

\section{Hasil Belajar Siswa}

Berdasarkan hasil penelitian selama proses pembelajaran pada siklus I diperoleh hasil belajar IPA pada tabel 2.

Tabel 2. Hasil Belajar IPA Siklus I.

\begin{tabular}{|c|c|c|c|c|}
\hline No & $\begin{array}{c}\text { Nilai } \\
\text { Tes }\end{array}$ & Frek & $\sum$ & Ket. \\
\hline 1 & 50 & 1 & 50 & $\begin{array}{c}\text { Belum } \\
\text { Tuntas }\end{array}$ \\
\hline 2 & 55 & 5 & 275 & $\begin{array}{c}\text { Belum } \\
\text { Tuntas }\end{array}$ \\
\hline 3 & 60 & 5 & 300 & $\begin{array}{c}\text { Belum } \\
\text { Tuntas }\end{array}$ \\
\hline 4 & 65 & 11 & 715 & Tuntas \\
\hline 5 & 70 & 3 & 210 & Tuntas \\
\hline 6 & 75 & 2 & 150 & Tuntas \\
\hline 7 & 80 & 1 & 80 & Tuntas \\
\hline 8 & 85 & 1 & 85 & Tuntas \\
\hline 9 & 90 & 1 & 90 & Tuntas \\
\hline \multicolumn{2}{|c|}{$\begin{array}{c}\text { Jumlah } \\
\text { Nilai }\end{array}$} & 30 & 1955 & - \\
\hline \multicolumn{2}{|c|}{ Rata-rata } & - & 65 & - \\
\hline
\end{tabular}

Berdasarkan data tersebut menunjukkan bahwa hasil belajar siswa kelas $\mathrm{V}$ pada suklus $\mathrm{I}$, siswa yang memperoleh nilai $<65$ ada 11 siawa dengan persentase $36,7 \%$, dan siswa yang memperoleh nilai $\geq 65$ sebanyak 19 siswa atau $63,3 \%$. Nilai tertinggi pada siklus I adalah 90 dan nilai terendah adalah 50 .

Pada tahapan refleksi,pelaksanaan pembelajaran pada siklus I denga nmenerapkan model pembelajaran penemuan terbimbingsudahsesuai dengan Rencana Perbaikan Pembelajaran(RPP) yang telah disusun. Namun terdapat beberapa indikator dan aspek yang harus diperbaikidalam siklus berikutnya. Halhal yang perlu diperbaiki pada kinerja guru antaralain:(1) Tidak semua siswa mendapat kesempatan untuk 
berinteraksi aktif dengan media pembelajaran yang digunakan yaitu hanya 8 siswa; (2) Siswa kurang aktif mengajukan pertanyaan/gagasan; (3) Guru kurang memotivasi siswa untuk memberikan respon terhadap materi (pertanyaan dan pernyataan) yang disampaikan oleh guru/temannya; (4) Siswa kurang aktif dalam membuat kesimpulan sendiri.

Berdasarkan permasalahan dan kegagalan di atas, maka guru dan peneliti mencari solusi untuk siklus ke2 yaitu : (1) Memberi kesempatan seluas-luasnya kepada seluruh siswa untuk mencoba/berinteraksi aktif dengan media alat pembelajaran yang digunakan dalam proses pembelajaran untuk mencoba menemukan adanya gaya magnet dan mengamati peristiwa yang terjadi saat melakukan percobaan, dan mencatat hasil pengamatannya Guru mempersiapkan materi pembelajaran, soal-soal latihan; (2) Pada kegiatan inti pembelajaran, setiap siswa diberi tugas untuk mengajukan/membuat minimal satu pertanyaan tentang materi yang diajarkan; (3) Lebih memotivasi siswa untuk aktif bertanya dan memberikan gagasan, memperbaiki kualitas dan cara bertanya, sehingga secara bertahap timbul keberanian pada diri siswa untuk bertanya dan memberikan gagasannya; (4) Guru membuat pertanyaan-pertanyaan penggiring, agar siswa mampu membuat kesimpulan sendiri.

Siklus II dilaksanakan sebanyak 2 kali pertemuan. Tahap perencanaan, sebelum dilaksanakan proses pembelajaran, peneliti melakukan persiapan sebagai berikut: menyiapkan silabus untuk menyusun rencana perbaikan pembelajaran dengan menggunakan model penemuan terbimbing untuk tindakan siklus I, menyiapkan alat peraga dan media pembelajara, menyiapkan lembar observasi untuk melihat kinerja guru selama pembelajaran, menyiapkan LKS yang diberikan pada siswa untuk lebih mudah memahami materi. Tahap pelaksanaanpertemuan 1, kegiatan pembelajaran berlangsung selama 2 jam pelajaran (2x35 menit), dengan tema pesawat sederhana. Pada siklus I pertemuan 2, kegiatan pembelajaran berlangsung selama 2 jam pelajaran (2x35 menit), dengan tema pesawat sederhana. Pada tahap pengaman, dilakukan guru sebagai pengajar, dan dosen sebagai peneliti dan observer. Observasi dilaksanakan secara langsung bersamaan dengan kegiatan pembelajaran berdasarkan lembar observasi yang telah dibuat dan disusun indikatornya. Dari pengamatan pada siklus I, masih terdapat siswa yang kurang aktif. Hal ini dikaranakan siswa masih belum terbiasa kerja kelompok. Terdapat siswa yang bermain-main dengan temannya, ada yang terlihat sibuk sendiri, kurang adanya interaksi siswa dengan guru. Hasil observasi meliputi hasil kinerja guru dan hasil belajar siswa diuraikan sebagai berikut

Analisis data hasil observasi menggunakan analisis persentase. Berdasarkan hasil penelitian kinerja guru selama proses pembelajaran pada siklus II pertemuan 1 dan 2 diperoleh hasil sesuai table 3 .

Tabel 3. Rekapitulasi Instrumen Penilaian Guru Siklus II

\begin{tabular}{|c|c|c|c|c|c|}
\hline No & Siklus I & Skor & \multicolumn{3}{|c|}{ Kategori } \\
\cline { 4 - 6 } & & A & CA & KA \\
\hline 1 & Pert 1 & $\begin{array}{c}91 \\
(78,45 \%)\end{array}$ & $\sqrt{ }$ & - & - \\
\hline 2 & Pert 2 & $\begin{array}{c}95 \\
(81,9 \%)\end{array}$ & $\sqrt{ }$ & - & - \\
\hline $\begin{array}{c}\text { Rata-rata } \\
\text { siklus 1 }\end{array}$ & $80,18 \%$ & - & - & - \\
\hline
\end{tabular}


Berdasarkan hasil dari tabel rekapitulasi instrumen penilaian kinerja guru pada pertemuan 1 jumlah skor yang diperoleh91 dengan $78,45 \%$, sedangkan pada pertemuan 2 , persentase penilaian kinerja guru meningkat menjadi 95 dengan persentase sebesar 81,90. Pada siklus II diperoleh rata-rata sebesar $80,18 \%$ dengan kategori aktif.

Hasil Belajar Siswa Siklus II

Berdasarkan hasil penelitian selama proses pembelajaran pada siklus II diperoleh hasil belajar pada table 4

Tabel 4. Hasil Belajar IPA k Siklus II.

\begin{tabular}{|c|c|c|c|c|}
\hline No & $\begin{array}{c}\text { Nilai } \\
\text { Tes }\end{array}$ & Frek & $\sum$ & Ket. \\
\hline 1 & 55 & 1 & 55 & $\begin{array}{l}\text { Belum } \\
\text { Tuntas }\end{array}$ \\
\hline 2 & 60 & 3 & 180 & $\begin{array}{l}\text { Belum } \\
\text { Tuntas }\end{array}$ \\
\hline 3 & 65 & 3 & 195 & Tuntas \\
\hline 4 & 70 & 1 & 70 & Tuntas \\
\hline 5 & 75 & 3 & 225 & Tuntas \\
\hline 6 & 80 & 4 & 320 & Tuntas \\
\hline 7 & 85 & 6 & 510 & Tuntas \\
\hline 8 & 90 & 2 & 180 & Tuntas \\
\hline 9 & 95 & 5 & 475 & Tuntas \\
\hline 10 & 100 & 2 & 200 & Tuntas \\
\hline \multicolumn{2}{|c|}{$\begin{array}{c}\text { Jumlah } \\
\text { Nilai }\end{array}$} & 30 & 2410 & - \\
\hline \multicolumn{2}{|c|}{ Rata-rata } & - & 80 & - \\
\hline
\end{tabular}

Berdasarkan data tersebut menunjukkan bahwa hasil belajar siswa kelas $\mathrm{V}$ pada siklus II, siswa yang memperoleh nilai $<65$ ada 4 siswa dengan persentase $13,3 \%$, dan siswa yang memperoleh nilai $\geq 65$ sebanyak 26 siswa atau $86,7 \%$. Berarti mengalami peningkatan $23,4 \%$ jika dibandingkan dengan siklus I yang hanya mencapai $63,3 \%$.

Pada tahapan refleksi, terjadi peningkatan dalam kinerja guru dan hasil belajar siswa. Hal ini dikarenakan (1) Dalam pembelajaran menggunakan alat peraga dapat memotivasi minat belajar siswa; (2) Adanya kegiatan siswa untuk membuat minimal satu pertanyaan; (3) Masing-masing siswa diberi kesempatan untuk menjawab pertanyaan dari temannya, (4) Guru memberikan pertanyaan kepada siswa dengan menggunakan bahasa yang sederhana, jelas, dan mudah dipahami siswa.; serta (5) Guru memberikan respon positif kepada siswa yang berpartisipasi aktif dan membantu siswa yang mengalami kesulitan dalam proses belajar.

\section{Rekapitulasi Aktivitas Guru Siklus I dan II}

Rekapitulasi aktivitas guru selama proses pembelajaran diperoleh ratarata siklus I diperoleh $73,27 \%$. Pada siklus II diperoleh rata-rata siklus II $80,18 \%$.

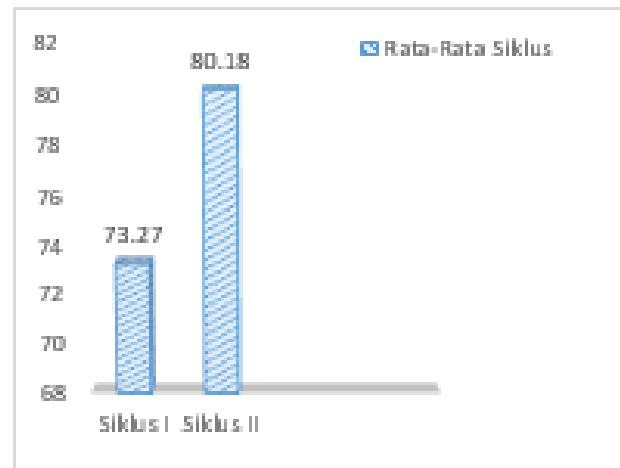

Gambar 1. Rekapitulasi Instrumen Penilaian Kinerja Guru Siklus I dan II Rekapitulasi Ketuntasan Hasil Belajar Siswa Siklus I dan II

Rekapitulasi ketuntasan hasil belajar siswa selama proses pembelajaran rata-rata siklus I 63,33\% dan siklus II diperoleh rata-rata sebesar $86,67 \%$, Pada siklus I ke siklus II terjadi peningkatan sebesar $23,34 \%$. 


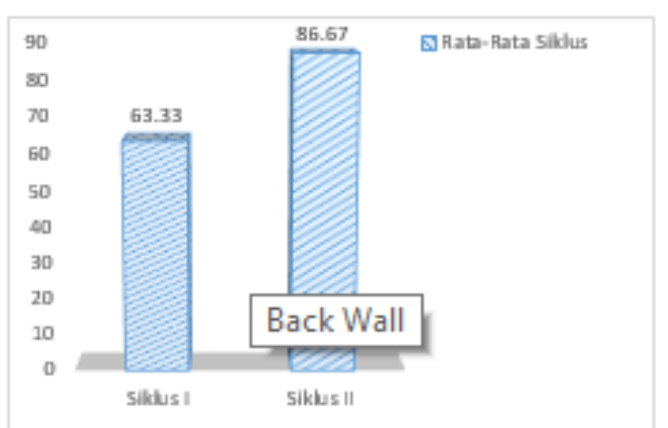

Gambar 2. RekapitulasiKetuntasan Hasil Belajar IPA siswa kelas V Siklus I dan II

Berdasarkan hasil penelitian yang sudah dilakukan,model pembelajaran penemuan terbimbing jikaditerapkan dengan langkah yang tepat dapat meningkatkan hasil belajar siswa, sesuai dengan Solihah (2006), bahwa dalam model pembelajaran penemuan terbimbing interaksi dapat terjadi, di antara siswa baik dalam kelompokkelompok kecil maupun kelompok besar (kelas), dan antara siswa dengan guru. Dalam melakukan aktivitas atau penemun dalam kelompok-kelompok kecil, siswa berinteraksi satu dengan yang lain. Sehingga, mempengaruhi kretaivitas siswa dalam menemukan sesuatu untuk menyelesaikan masalah.

\section{SIMPULAN}

Berdasarkan hasil penelitian dan pembahasan yang disajikan sebelumnya, maka pembelajaran dengan menggunakan model pembelajaran penemuan terbimbing dapat meningkatkan hasil belajar IPA kelas V SD Negeri 10 Metro Timur, yang ditujukkan pada persentase ketuntasan hasil belajar dari siklus I sebasar $63,33 \%$ menjadi $86,67 \%$ pada siklus II. Dalam penerapan model pembelajaran penemuan terbimbing ditemukan kendala dalam pelaksanaannya. Pembelajaran penemuan terbimbing berjalan kurang optimal, sehingga diharapkan merencanakan pembelajaran dengan lebih baik sesuai dengan tahapantahapan dengan membuat rencana pelaksanaan pembelajaran dan sebelum instrumen test maupun non test digunakan perlu ada analisis pada instrument melihat kesesuaian instrument test dan non test, selain itu guru diharapkan dapat merancang metode dan media dalam pembelajaran konvensional untuk dapat meningkatkan hasil belajar siswa.

\section{DAFTAR PUSTAKA}

Angkowo, Robertus. Kosasih A. Arikunto, Suharsimi, dkk. (2006). (2007). Optimalisasi Media Penelitian Tindakan Kelas. Pembelajaran. Jakarta: PT Jakarta: PT Bumi Aksara Grasindo.

Ahmad, Hamzah, dkk. (2000). Kamus Pintar Bahasa Indonesia. Surabaya: Fajar Mulyana
Arikunto, Suharsimi, dkk. (2007). Dasar-Dasar Evaluasi Pendidikan. Jakarta: PT Bumi Aksara 
Badan Stantar Nasional Pendidikan. 2006. Panduan penyusunan KTSP Jenjang Pendidikan Dasar dan Menengah. Jakarta: departemen Pendidikan Nasional.

Dahar, RW., 1996. Teori-Teori Belajar. Penerbit Erlangga, Jakarta.

Hadiningsih, R. 2009. Kefektifan Metode Penemuan Terbimbing dan Metode Pemberian Tugas terhadap Prestasi Belajar Matematika ditinjau dari Motivasi Belajar Siswa Kelas 8. Surakarta: Universitas Sebelas Maret Press.

Khairudin dan Suedjono. 2005;15. Strategi pembelajaran. 2009. Diknas.
Markaban, 2006. Model Pembelajaran IPA. Dengan Pendekatan Penemuan Terbimbing. Yogyakarta. Depdiknas Pusat pengembangan dan Penataran Guru IPA.

Solihah, I. 2006. Kreativitas Berfikir Siswa melalui Pendekatan Guided Discovery dalam Konsep Reproduksi Tumbuhan SMAN 6 Bandung. Skripsi S1 Pendidikan Biologi. FMIPA UPI. Tidak diterbitkan

Sudjana, N. 2005. Penilaian Hasil Proses Belajar Mengajar. Bandung: PT Remaja Rosdikarya 